\title{
Climate impacts in the Brazilian energy security: analysis of observed events and adaptation options
}

Impactos climáticos na segurança energética no Brasil: análise de eventos observados e opções de adaptação

Eveline Vasquez-Arroyo ${ }^{\mathrm{a}}$

Fábio da Silvab

Alberto Santos ${ }^{c}$

Deborah Cordeiro $^{d}$

José Antônio Marengo ${ }^{\mathrm{e}}$

André F. P. Lucena ${ }^{f}$

${ }^{a}$ Energy Planning Program, Alberto Luiz Coimbra Institute of Graduate Studies and Engineering Research, Federal University of Rio de Janeiro, Rio de Janeiro, RJ, Brazil E-mail: eveline@ppe.ufrj.br

${ }^{b}$ Energy Planning Program, Alberto Luiz Coimbra Institute of Graduate Studies and Engineering Research, Federal University of Rio de Janeiro, Rio de Janeiro, RJ, Brazil E-mail: fabioteixeira@ppe.ufrj.br

'Energy Planning Program, Alberto Luiz Coimbra Institute of Graduate Studies and Engineering Research, Federal University of Rio de Janeiro, Rio de Janeiro, RJ, Brazil E-mail: albertojlsantos@ppe.ufrj.br

${ }^{d}$ Energy Planning Program, Alberto Luiz Coimbra Institute of Graduate Studies and Engineering Research, Federal University of Rio de Janeiro, Rio de Janeiro, RJ, Brazil E-mail: deborahcordeiro@ppe.ufrj.br

${ }^{e}$ Center for Monitoring and Early Warnings of Natural Disasters - Cemaden,

São José dos Campos, SP, Brazil E-mail: jose.marengo@cemaden.gov.br

${ }^{f}$ Energy Planning Program, Alberto Luiz Coimbra Institute of Graduate Studies and Engineering Research, Federal University of Rio de Janeiro, Rio de Janeiro, RJ, Brazil E-mail: andrelucena@ppe.ufrj.br doi:10.18472/SustDeb.v11n3.2020.33838 
The data and results presented in this publication were developed under the project "Fourth National Communication and Biennial Update Reports from Brazil to the Climate Convention", coordinated by the Ministry of Science, Technology, and Innovation, with support from the United Nations Development Program, with resources from the Global Environment Facility, to which we express our gratitude.

\section{ABSTRACT}

Climate change is expected to increase the frequency and intensity of extreme weather events, which can affect energy systems. This study aims to evaluate impacts of meteorological extreme events on the Brazilian energy system, through an analysis of recent reports. Cases of impacts on hydroelectric plants, power transmission and distribution lines, bioenergy crops, and residential cooling energy demand in recent years are assessed. Finally, the challenges of energy planning in the face of climate change are analyzed and adaptation measures for the energy system are proposed, pointing out possible repercussions on water, food, socio-environmental and climate security.

Keywords: Climate change. Impact. Adaptation. Energy security. Brazil.

\section{RESUMO}

As mudanças climáticas poderão aumentar a ocorrência e intensidade de eventos climáticos extremos, que podem afetar os sistemas de energia. Assim, este estudo objetiva identificar impactos de eventos meteorológicos que tiveram influência sobre o sistema energético brasileiro, por uma análise de relatos recentes. São levantados e avaliados casos de impactos em hidrelétricas, sistemas de transmissão e distribuição de energia elétrica, produção de culturas bioenergéticas e demanda de energia elétrica do setor residencial. Por último, analisam-se os desafios do planejamento energético diante das mudanças climáticas e propõem-se medidas de adaptação, apontando suas possíveis repercussões na segurança hídrica, alimentar, socioambiental e climática.

Palavras-chave: Mudanças climáticas. Impacto. Adaptação. Segurança energética. Brasil.

\section{INTRODUCTION}

Climate change brings an extensive list of environmental and socioeconomic impacts on different factors, such as biodiversity, coastal areas, water supply, agriculture, food security, health, energy, etc., which can affect the population and the sustainability of the planet (ALBERTO, 2006; LELIS et al., 2011; MARENGO, 2004).

The availability of primary sources, conversion, transport, and end-use of energy can have a direct or indirect relation to climatic variables. However, climate change is related to the increase in the concentration of greenhouse gases (GHG) in the atmosphere (IPCC, 2014). These changes, by means of changes in temperature, precipitation and wind speed, can generate benefits in the energy sector in certain regions and resources, but a deterioration in other sectors.

Hydropower is currently responsible for about $11 \%$ of the primary energy and $67 \%$ of the total electricity generation in Brazil (EPE, 2019). The lack of precipitation impacts this technology by reducing water inflows both for run-of-river plants and for reservoirs. This generates a reduction in the useful volume of reservoirs and, consequently, in the energy buffer storage service they provide (SCHAEFFER et al., 2012). Hence, this technology is vulnerable to extreme weather events, such as droughts. Several studies indicate impacts of drought on hydropower in Brazil, mainly in the North and Northeast regions (ARIAS et. al, 2020; LUCENA et al., 2009). Schaeffer et al. (2015) state that the high risk of supply deficit for hydropower due to climate change requires massive investments in new electricity generation capacity from other sources. 
Impacts of drought on hydropower are not restricted to Brazil. In California (USA), the average share of hydroelectricity on the state's energy mix dropped from a historical average of $18 \%$ to $10.5 \%$ in the drought season of 2011 to 2015, reaching only 7\% in the 2015 water year (GLEICK, 2016).

Wind power depends on the regime, intensity, and direction of winds. However, wind gusts can impact the operation and design of wind turbines (IPCC, 2011). Studies in Brazil indicate that the wind power potential would not be significantly impacted. Climate projections showed an increase in wind power potential over time, especially in the Northeast and South regions (JONG et al., 2019; LUCENA et al., 2010; PEREIRA et al., 2013). Nevertheless, wind resources could be impacted in other places. Examples are the northwestern region of the United States, where the potential could be reduced by up to $40 \%$ (SAILOR et al., 2008), and Southern Europe with a reduction of $10 \%$ in wind potential (TOBIN et al., 2015).

Solar photovoltaic (PV) energy depends mainly on solar radiation, wind speed on the surface, and ambient temperature. Higher solar resources tend to increase generation, while higher temperatures lead to lower efficiency of the panel (GARCÍA; BALENZATEGUI, 2004; SIMIONI; SCHAEFFER, 2019; SINGH; RAVINDRA, 2012).

Studies suggest that the photovoltaic potential in Brazil would not be considerably affected in the future due to projections of a simultaneous increase in solar radiation and temperature in much of the country (SANTOS, 2020). In Europe, a modest increase in potential in the Mediterranean region is projected, as well as a decrease of $10 \%$ to $12 \%$ in this potential in Scandinavia (JEREZ et al., 2015).

Also, extreme weather events pose high risks to power transmission and distribution system. Hence, the extension of impacts tends to be higher for large infrastructures, such as the National Interconnected System (SIN) in Brazil.

In the biofuel sector, the main impacts of climate change are associated with the supply of bioenergy crops (SCHAEFFER et al., 2012). The main biofuels in Brazil are ethanol and biodiesel. For ethanol, almost the whole production comes from sugarcane (UNICA, 2020). The production of biodiesel rely on a more diverse set of oil crops, but the most relevant is soybean oil, which was responsible for around $68 \%$ of the biofuel production in 2019 (ANP, 2020). Thus, climate changes affecting the agro-ecological zoning of these crops have the potential to impact the biofuels sector in Brazil.

The impacts of climate change in the energy sector are not limited to the supply, but can also affect the demand. Changes in temperature and humidity can lead to a higher demand for ambient cooling or heating (CLARKE et al., 2018; INVIDIATA; GHISI, 2016; SCHAEFFER et al., 2012). This affects mostly the building sector and may be even more significant with the increase in income and possession of air conditioners. In Australia, Hatvani-Kovacs (2016) identified a correlation between peak energy demand and the increase in the daily temperature recorded due to heatwaves, with an average increase in electricity demand of $6.35 \%$ by $1^{\circ} \mathrm{C}$ increase at the maximum daily temperature. Phoenix and Washington DC showed a $3.6 \%$ increase in demand for each degree of temperature increase (FRANCO, 2008).

In the present study, cases of extreme weather events recently observed that may occur more frequently due to climate change - such as droughts, intense precipitation, and heatwaves - and their effects on the Brazilian energy system are presented. The study also discusses how impacts could be reduced through adaptation measures. Adaptation options are assessed in an integrated basis with external aspects that also influence the country's energy security, such as socioeconomic, political, and environmental aspects. 


\section{METHODS}

First, cases of extreme weather events observed in the last 20 years in Brazil were identified. Reports of droughts, cyclones and heatwaves were surveyed in the scientific literature and also in gray literature publications.

Then, according to the type of observed event and its location, data on the behavior of the energy system in the same time interval were collected. For this, public databases from official Brazilian institutions, such as ONS and EPE were used. Impacts on hydropower generation, transmission and distribution of electricity, the biofuels sector, and residential energy demand for cooling were evaluated.

Finally, extreme weather events and their impacts on the energy system were correlated in tables, divided by the impacted segments of the energy sector. The samples were classified by region, period, and type of event, with a qualitative description of their impact.

\section{RESULTS}

\subsection{IMPACTS OBSERVED IN THE HYDROELECTRIC POWER GENERATION}

In 2014, there was a hydrological drought in the Southeast Region, which impacted the head of the São Francisco Hydrographic Region and, consequently, downstream users, located in the Northeast Region.

The Três Marias Hydroelectric Power plant is a large multi-purpose hydraulic enterprise located in the Southeast Region of Brazil. It currently has an installed capacity of $396 \mathrm{MW}$, with six generating units and a storage volume of $19,528 \mathrm{hm}^{3}$ (CEMIG, 2019). Três Marias is the head of a set of cascading plants that feed other reservoir plants located downstream, such as Sobradinho and Itaparica, and run-ofriver plants, such as Moxotó, Paulo Afonso, and Xingó (Figure 1). Thus, its operation is crucial for the regulation of the São Francisco River, mainly in the stretch between the Três Marias reservoir and the Sobradinho hydroelectric plant, in Bahia.

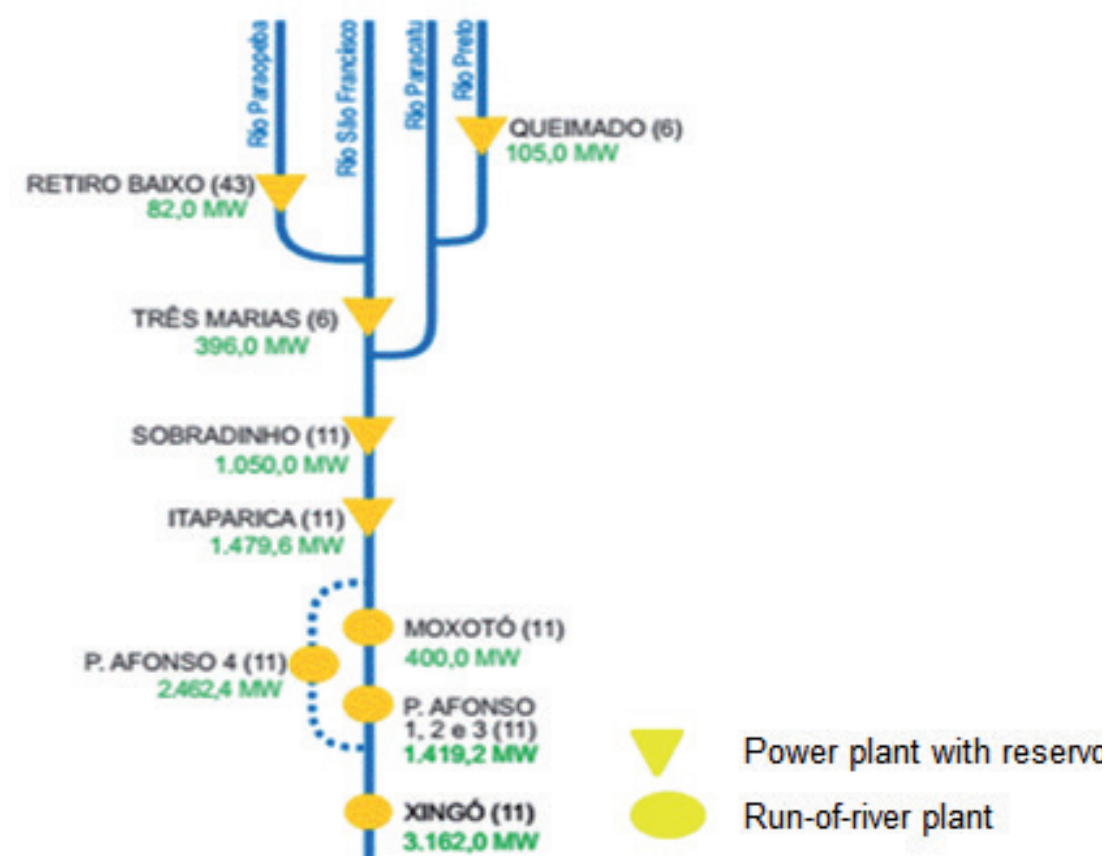

Figure 1 | Schematic chart of the SIN hydroelectric plants in the São Francisco River basin. 
An analysis of the last 19 years shows that the hydropower plant encountered operational difficulties due to low storage in relation to its useful volume in some periods, reaching an annual average of less than 30\%, especially in the years 2001, 2014, 2015, 2016, and 2017 (ANA, 2019). As of 2011, the São Francisco River basin recorded negative rainfall anomalies, with a $40 \%$ reduction in rainfall in 2012 (MARTINS; FRANCISCO JÚNIOR, 2017). The north and mid-east of the Northeast Region recorded a decrease between $20 \%$ and $40 \%$ in annual precipitation in the years 2014 and 2015 (MARTINS; FRANCISCO JÚNIOR, 2017).

These conditions led to a decrease in the level of reservoirs in the São Francisco River basin between 2012 and 2017. The most critical period was between September 2014 and February 2015, when the useful volume was below $10 \%$ of its capacity, reaching $2.9 \%$ in November 2014 (ANA, 2019). Over the following years, the reservoir was unable to fully recover, and in 2017 the useful volume reached $6 \%$ (ANA, 2019). During the droughts faced in the Southeast Region, the reservoir guaranteed the needs of human supply and animal desedentation, which are by law the priority uses of water (BRASIL, 1997).

This caused the plant to run only two out of the six installed turbines. Três Marias reduced its generation from 188 MWmed in March 2013 down to 28 MWmed in March 2015. Such reduction in generation is directly related with the reduction in the useful volume of the reservoir.

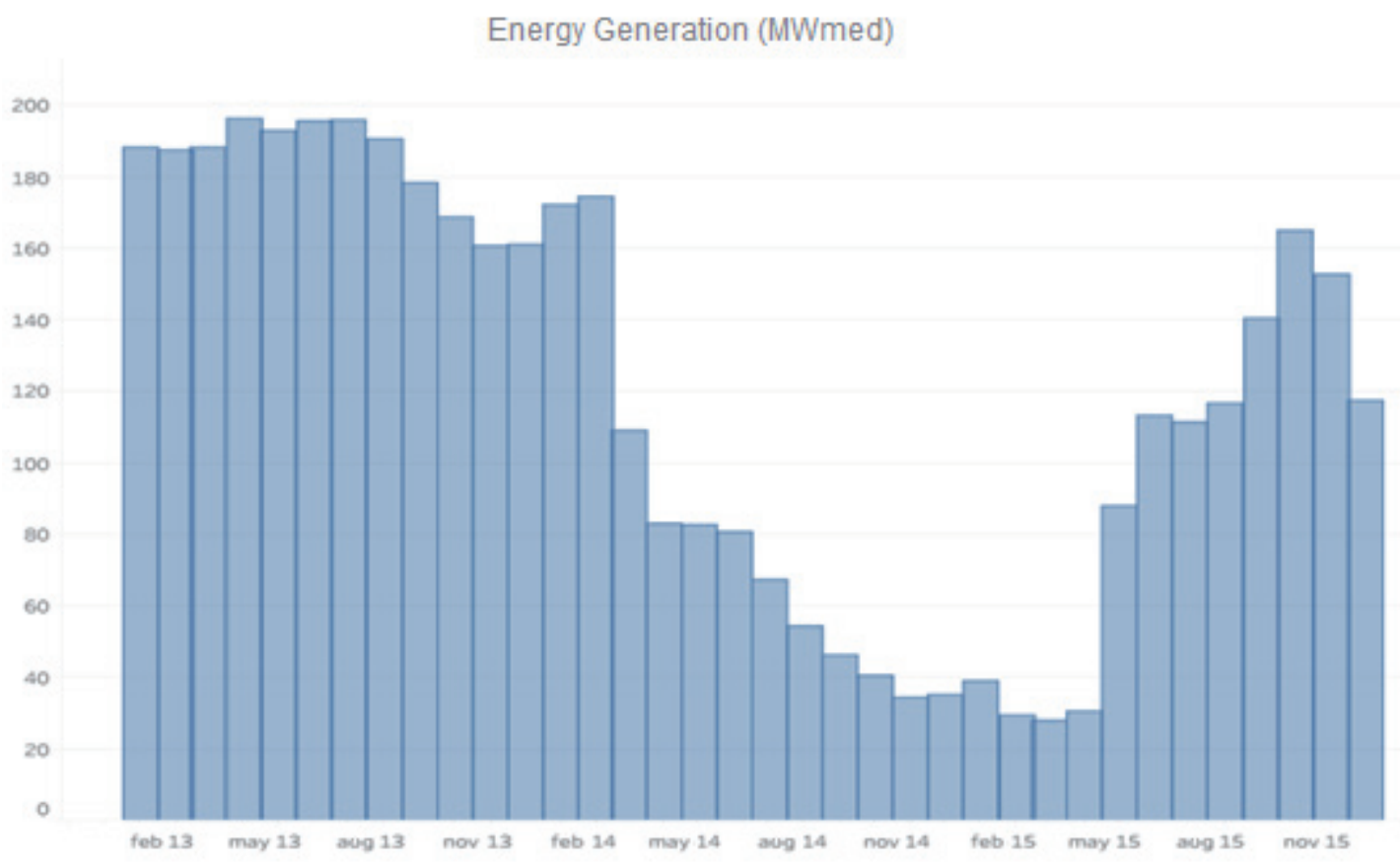

Figure 2 | Mean generation (MWmed) of the Três Marias Hydroelectric Plant from 2013 to 2015.

Source: ONS, 2020.

The hydroelectric plants located downstream were impacted by the drought in the Southeast (2014) and droughts in the Northeast (2013 to 2017), as shown in Figure 3. Sobradinho recorded a gradual decline in its mean generation. In 2014, the plant had a useful volume of $60 \%$ and reached $20 \%$ in December 2015 (ONS, 2020). In 2017, drought conditions prevailed and the reservoir reached a maximum value close to $15 \%$. The minimum generation amount of Sobradinho dropped $105 \mathrm{MWmed}$ in November 2017, from 356 MWmed recorded in 2013 (ONS, 2020).

The Itaparica reservoir recorded a drop in its useful volume (40\%) from 2013, and with the impact of Três Marias, it reached 14\% (ANA, 2020; ONS, 2020). With the persistence of the drought in the Northeast, the useful volume of the reservoir reached 9\% in November 2015 (ANA, 2020). In 2017, the useful volume fell rapidly again, reaching $7 \%$ in January (ANA, 2020). Also, the Paulo Afonso and 
Xingó plant complex, located immediately downstream, observed a slight reduction in the average generation from 2014. In a way, the impacts on the plants decrease as they are more distant from the Três Marias plant.

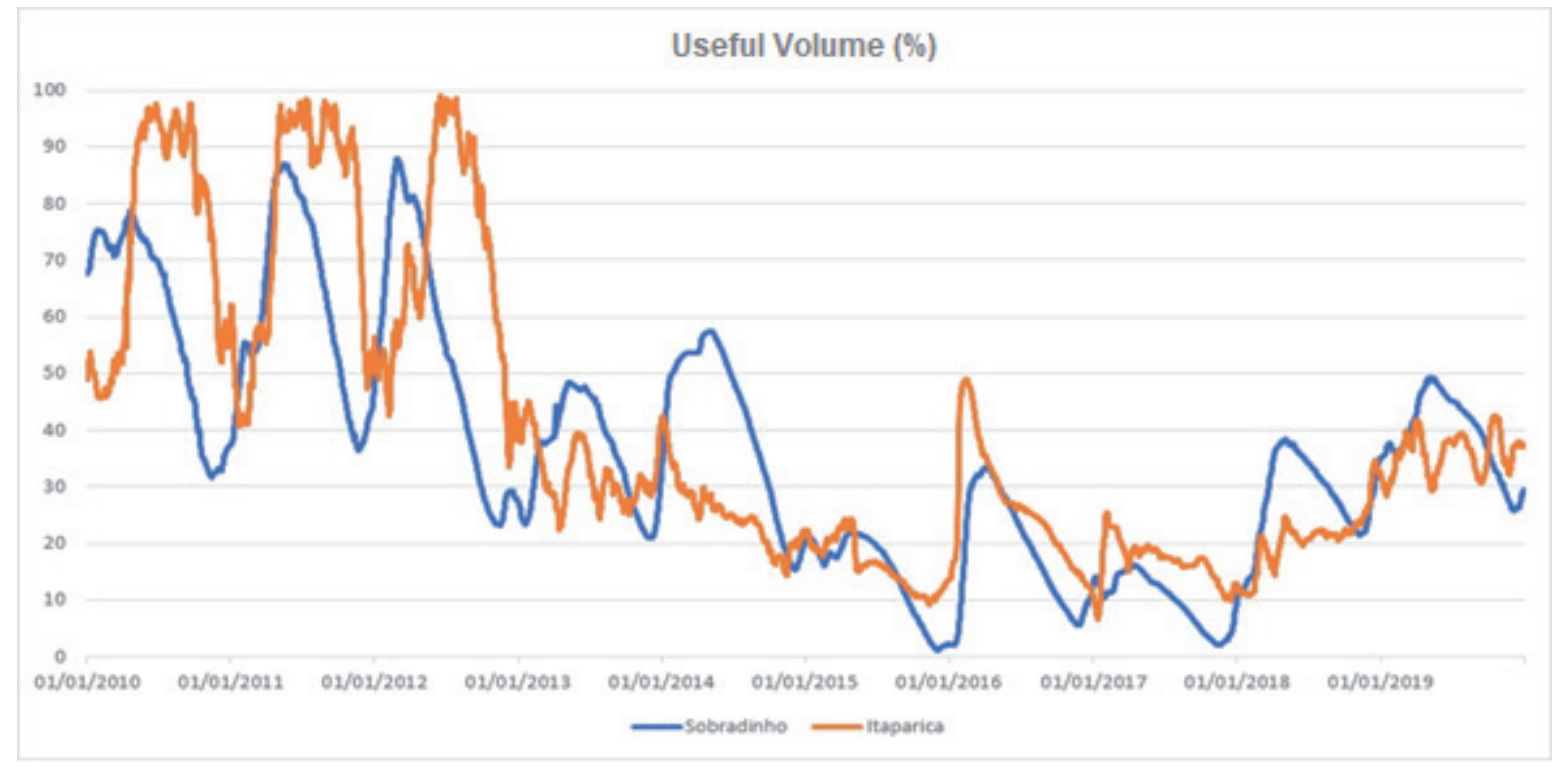

Figure 3 | Useful volume of Sobradinho and Itaparica from 2010 to 2020.

Source: the authors of this study, based on ANA (2020).

Table 1 shows a summary of the impacts observed on hydroelectric generation in other locations, between 2012 and 2020.

Table 1 | Impacts observed by extreme events in the hydroelectric supply between 2012 and 2020

\begin{tabular}{|c|c|c|c|c|}
\hline Year & Region & $\begin{array}{l}\text { Type of cli- } \\
\text { mate impact }\end{array}$ & Description of the event & Reference \\
\hline 2012 - 2017 & $\begin{array}{l}\text { Northeast } \\
\text { region } \\
\text { (Semiarid) }\end{array}$ & Drought & $\begin{array}{l}\text { Decrease in affluent natural energy (ANE) and the } \\
\text { volume of hydroelectric reservoirs and therefore, } \\
\text { the stored energy of the Northeast Subsystem. } \\
\text { Reservoirs in the São Francisco River basin were } \\
\text { greatly affected by droughts, such as Três Marias } \\
\text { and Sobradinho. In Três Marias, the useful volume } \\
\text { reached } 2.6 \% \text { in } 2014,7 \% \text { in } 2015 \text {, and } 6 \% \text { in } 2017 . \\
\text { In Sobradinho, useful volume reached lows of } 1 \% \\
\text { in } 2015,6 \% \text { in } 2016 \text {, and } 2 \% \text { in } 2017 \text {. In Itaparica, } \\
\text { the minimum values of useful volume were } 14 \% \\
\text { in } 2014,9 \% \text { in } 2015 \text {, and } 7 \% \text { in } 2017 \text {. The energy } \\
\text { stored in the Northeast subsystem started to decline } \\
\text { from } 2013, \text { reaching a minimum value of } 4 \% \text { in } \\
\text { November } 2015 \text { and November } 2017 \text {. }\end{array}$ & $\begin{array}{c}\text { CUNHA et al., } \\
2019 \mathrm{a} \\
\text { CUNHA et al., } \\
2019 \mathrm{~b} \\
\text { CEMADEN, } \\
2016 \\
\text { MARTINS \& } \\
\text { MAGALHÃES, } \\
2015 \\
\text { MARENGO et } \\
\text { al., } 2018 \\
\text { ONS, } 2020\end{array}$ \\
\hline $\begin{array}{c}\text { summer } \\
2013-2014 \\
2014-2015\end{array}$ & $\begin{array}{l}\text { Southeast } \\
\text { region } \\
\text { (São Paulo } \\
\text { and Minas } \\
\text { Gerais) }\end{array}$ & Drought & $\begin{array}{l}\text { Decrease in the volume of hydroelectric reservoirs, } \\
\text { which resulted in declines in affluent natural energy } \\
\text { and energy stored in the Southeast/Midwest } \\
\text { Subsystem. The Southeast subsystem recorded a } \\
\text { minimum percentage of } 15 \% \text { of stored energy in } \\
\text { November 2014, much lower than the } 42 \% \text { recorded } \\
\text { in November } 2013 \text {. }\end{array}$ & $\begin{array}{l}\text { CUNHA et al., } \\
2019 b \\
\text { MARENGO et } \\
\text { al., } 2015 \\
\text { NOBRE et al., } \\
2016 \\
\text { ONS, } 2020\end{array}$ \\
\hline $2015 / 2016$ & $\begin{array}{l}\text { North region } \\
\text { (Amazon) }\end{array}$ & Drought & $\begin{array}{l}\text { Decrease in the level of hydroelectric reservoirs } \\
\text { and consequent decrease in affluent natural energy } \\
\text { and energy stored in the North Subsystem. The } \\
\text { stored energy also dropped considerably between } \\
2015 \text { and } 2016 \text {. After exceeding } 90 \% \text { in } 2014 \text {, the } \\
\text { maximum stored energy dropped to } 81 \% \text { in } 2015 \\
\text { and to } 65 \% \text { in } 2016 \text {. }\end{array}$ & $\begin{array}{c}\text { CUNHA et al., } \\
\text { 2019b } \\
\text { WANDERLEY } \\
\text { et al., } 2018 \\
\text { ONS, } 2020\end{array}$ \\
\hline
\end{tabular}




\begin{tabular}{|c|c|c|c|c|}
\hline Year & Region & $\begin{array}{c}\text { Type of cli- } \\
\text { mate impact }\end{array}$ & Description of the event & Reference \\
\hline 2019-2020 & $\begin{array}{c}\text { South region } \\
\text { (Paraná and } \\
\text { Rio Grande } \\
\text { do Sul) }\end{array}$ & Drought & $\begin{array}{c}\text { Decrease in the volumes of hydroelectric reservoirs } \\
\text { in the South subsystem and a decrease in affluent } \\
\text { natural energy and energy stored in reservoirs } \\
\text { present in the South subsystem due to drought in } \\
\text { the southern states between 2019 and 2020. The } \\
\text { volume of energy stored in the South subsystem } \\
\text { registered the lowest value in at least 20 years, } \\
\text { reaching the percentage of } 14 \% \text { in April 2020, much } \\
\text { lower than the 28\% registered in April 2000, which } \\
\text { was the lowest value in this period. }\end{array}$ & $\begin{array}{c}\text { CEMADEN, } \\
\text { ONS, 2020 }\end{array}$ \\
\hline
\end{tabular}

Source: The authors of this study

\subsection{IMPACTS OBSERVED IN THE POWER TRANSMISSION AND DISTRIBUTION SYSTEM}

Power transmission is a fundamental operation for the Brazilian electrical system. The transmission lines have the main role of interconnecting the hydrographic basins, optimizing the use of water resources throughout the country. SIN's electricity supports about $96 \%$ of the country's total power energy production capacity by connecting the South, Southeast, Midwest, Northeast, and part of the North Region (ANEEL, 2005). Electricity transmission and distribution lines are especially vulnerable to events of intense precipitation accompanied by strong winds (ANEEL, 2018). Events such as extratropical cyclones also cause intense rains and wind. These have already affected the transmission and distribution system in southern Brazil in recent years, such as the Catarina cyclone in 2004 and the bomb cyclone in 2020.

Damage to the infrastructure of the electricity distribution and transmission system directly affects the energy security by interrupting the transport of electricity to end-users. In June 2020, a cyclone interrupted the supply of electricity to 1.5 million consumer units and caused a loss of more than $\mathrm{R} \$ 60$ million electricity generation and distribution system in Santa Catarina (CELESC, 2020).

Another important aspect is the cost for repairing damaged system, which can be passed on to the consumers. This was the case with Celesc, a utility company in the state of Santa Catarina, in which the Brazilian Electricity Regulatory Agency (ANEEL as in its Portuguese acronym) authorized a $0.45 \%$ increase in the electricity price, related to the losses resulting from the reconstruction of networks destroyed by Cyclone Catarina (ANEEL, 2004). Eletrosul (2014) indicates that the company included in the insurance policies of its operating generation and transmission assets the coverage for claims arising from gale, cyclone, hurricane, hail, flooding, earthquake and fire.

Table 2 shows a summary of the impacts on the transmission and distribution of electricity between 2004 and 2020. 
Table 2 | Impacts by extreme events in the transport of electricity: transmission and distribution,

\section{between 2004 and 2020.}

\begin{tabular}{|c|c|c|c|c|}
\hline Year & Region & $\begin{array}{l}\text { Type of cli- } \\
\text { mate impact }\end{array}$ & Description of the event & Reference \\
\hline 2004 & $\begin{array}{c}\text { Santa } \\
\text { Catarina }\end{array}$ & $\begin{array}{l}\text { Catarina } \\
\text { cyclone }\end{array}$ & $\begin{array}{l}\text { Strong winds knocked down about } 1,000 \text { poles } \\
\text { in Santa Catarina and destroyed at least } 250 \\
\text { transformers, leaving municipalities, such as } \\
\text { Araranguá, Criciúma, Passo de Torres, Maracajá, } \\
\text { and Sombrio without power supply. }\end{array}$ & $\begin{array}{l}\text { PEZZA, } \\
\text { SIMMONDS, } \\
\& \text { FILHO, } 2008\end{array}$ \\
\hline 2008 & $\begin{array}{l}\text { Santa } \\
\text { Catarina }\end{array}$ & $\begin{array}{l}\text { Extreme } \\
\text { rains }\end{array}$ & $\begin{array}{l}\text { Losses and damages amounted to } \mathrm{R} \$ 74 \text { million } \\
\text { (2009), mainly due to the need to repair } \\
\text { transmission lines, poles and towers, and for } \\
\text { damage to gas pipelines. }\end{array}$ & $\begin{array}{c}\text { WORLD } \\
\text { BANK, 2012B }\end{array}$ \\
\hline 2010 & Pernambuco & Heavy rain & $\begin{array}{l}\text { Losses and damages amounted to almost } \mathrm{R} \$ 13 \\
\text { million. } 589 \text { posts, } 8,500 \text { meters, } 41 \text { transformers, } \\
183 \text { reflectors, and } 132 \text { kilometers of cable were } \\
\text { replaced. }\end{array}$ & $\begin{array}{c}\text { WORLD } \\
\text { BANK, 2012a }\end{array}$ \\
\hline 2011 & $\begin{array}{l}\text { Mountain } \\
\text { region of Rio } \\
\text { de Janeiro }\end{array}$ & Heavy rain & $\begin{array}{l}\text { A loss of more than } \mathrm{R} \$ 35 \text { million was estimated } \\
\text { due to damages and losses in the electricity supply } \\
\text { infrastructure. } 75,000 \text { people were left with no } \\
\text { power supply after the event. }\end{array}$ & $\begin{array}{c}\text { WORLD } \\
\text { BANK, 2012C }\end{array}$ \\
\hline 2012 & $\begin{array}{l}\text { Rio Grande } \\
\text { do Sul }\end{array}$ & $\begin{array}{l}\text { Strong } \\
\text { wind / } \\
\text { Heavy rain }\end{array}$ & $\begin{array}{l}\text { About } 530 \text { thousand consumer units were left } \\
\text { without electricity in Rio Grande do Sul after a } \\
\text { storm in December } 2012 \text {. }\end{array}$ & CEEE, 2012 \\
\hline 2015 & $\begin{array}{l}\text { Santa } \\
\text { Catarina }\end{array}$ & Tornado & $\begin{array}{l}\text { Damage to the electricity transmission system. } \\
\text { In the state, } 11 \text { power transmission towers were } \\
\text { affected. This was Celesc's biggest accident in } 60 \\
\text { years. }\end{array}$ & $\begin{array}{c}\text { Câmara dos } \\
\text { deputados } \\
\text { do Brasil } \\
\text { (Brazilian } \\
\text { lower federal } \\
\text { chamber), } \\
2017\end{array}$ \\
\hline 2016 & $\begin{array}{l}\text { Rio Grande } \\
\text { do Sul }\end{array}$ & $\begin{array}{l}\text { Strong } \\
\text { wind / } \\
\text { Heavy rain }\end{array}$ & $\begin{array}{l}\text { A storm left about } 450 \text { thousand consumer units of } \\
\text { the CEEE concessionaire with no power supply in } \\
\text { Porto Alegre. Two substations were out of operation } \\
\text { and } 125 \text { feeders had no power. }\end{array}$ & CEEE, 2016 \\
\hline 2020 & South region & $\begin{array}{l}\text { Strong } \\
\text { wind / } \\
\text { Heavy rain } \\
\text { / extra- } \\
\text { tropical } \\
\text { cyclone }\end{array}$ & $\begin{array}{l}\text { In the state of Santa Catarina, about } 1.5 \text { million } \\
\text { consumer units were left without access to } \\
\text { electricity after the bomb cyclone. A loss of } 63 \\
\text { million is estimated in the state's electricity } \\
\text { generation and distribution system. Celesc, the } \\
\text { largest electricity concessionaire in Santa Catarina, } \\
\text { reported that the damage caused to the state's } \\
\text { electricity grid was the largest in history. In Rio } \\
\text { Grande do Sul, the distributor CEEE reported } \\
\text { that } 750 \text { thousand customers were left without } \\
\text { electricity after the cyclone. }\end{array}$ & $\begin{array}{l}\text { INMET, } 2020 \\
\text { CELESC, } 2020 \\
\text { DEFESA CIVIL } \\
\text { DO ESTADO } \\
\text { DE SANTA } \\
\text { CATARINA } \\
\text { (Santa } \\
\text { Catarina State } \\
\text { Civil Defense), } \\
2020\end{array}$ \\
\hline
\end{tabular}

Source: The authors of this study

\subsection{IMPACTS OBSERVED IN THE ELECTRICTY DEMAND FOR BUILDING (RESIDENTIAL SECTOR)}

Considering the demand for electricity, the building sector (residential and services) participates with $42 \%$, followed by the industrial sector with $32 \%$, the energy sector with $5 \%$, agriculture with $5 \%$, and transport with $0.4 \%$ (EPE, 2019). Increases in temperature force an increase in the demand for electricity due to greater use of air conditioning. The thermal conditioning of environments, which appears as an adaptive measure to climate change to keep populations at comfortable temperatures, is also an obstacle to the decarbonization of the energy system. The increase in the use of devices for cooling directly influences peak demand (SIVAK, 2009). 
Heatwaves were recorded in 2019. Rio de Janeiro showed a temperature $5^{\circ} \mathrm{C}$ above the maximum climatological average (1961 - 1990), which lasted 22 days in January (EPE, 2019a). The maximum monthly average was 37.4 으, 7.3 으 C above the maximum normal average (1961-1990) of 30.1으, surpassing the previous record of the highest maximum average, recorded for the month in 2014 (INMET, 2019a).

In January 2019, the city of São Paulo recorded 14 days of maximum temperatures above the climatological average (1961-1990). The Inmet station at Mirante de Santana registered the record at $35.1^{\circ} \mathrm{C}$ on January 30 , more than $7^{\circ} \mathrm{C}$ above the historical average for the month (1961-1990). Under this heatwave, residential electricity consumption increased by $8.0 \%$ in the residential sector (Figure 4) with an emphasis on the Southeast Region, which grew $8.3 \%$ compared to January 2018. The state of Rio de January had an increase close to $8 \%$, and in São Paulo residential consumption grew $7.3 \%$, considering the rate adjusted to the billing cycle (EPE, 2019a).

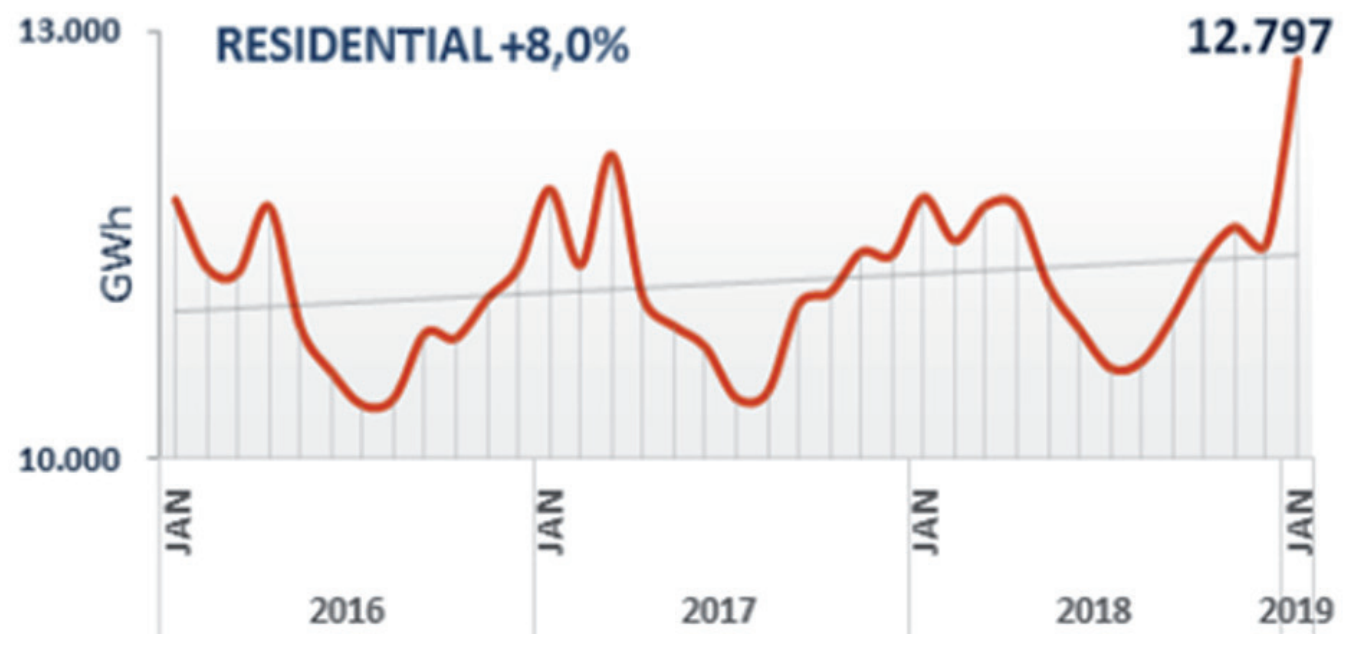

Figure 4 | Increase in residential consumption, in GWh.

Source: EPE, 2019a

In September 2019, a heatwave hit part of the Southeast and Midwest regions. The temperature remained 5 ㅇ C above a historical average (1961 to 1990) for the month, for a period longer than five days (INMET, 2019c). In Cuiabá (MT) the maximum temperatures remained above the historical average for the month for 17 days (INMET, 2019b). Electricity consumption in the Midwest Region in that month had an increase of $13.4 \%$ compared to the same period in the previous year, with emphasis on the states of Mato Grosso and Mato Grosso do Sul with a positive deviation of consumption of $18.5 \%$ and $28.9 \%$, respectively, pointing to an impact of higher temperatures in the region (EPE, 2019b). Table 3 shows the impact of heatwaves on the electricity demand by the Brazilian residential sector between 2010 and 2019. 
Table 3 | Impacts of heatwaves on residential electricity demand between 2010 and 2019

\begin{tabular}{|c|c|c|c|c|}
\hline Year & Region & $\begin{array}{l}\text { Type of cli- } \\
\text { mate impact }\end{array}$ & Description of the event & Reference \\
\hline 2010 & Southeast & Heatwave & $\begin{array}{l}\text { Rio de Janeiro maintained high temperatures for } \\
\text { eight consecutive days in February, with a deviation } \\
\text { of } 11.8 \text { o C from the historical average, between } 1961 \\
\text { to } 1990 \text {. Also, in February, the Southeast region } \\
\text { presented an increase of } 9.7 \% \text { compared to the } \\
\text { same period of the previous year. }\end{array}$ & $\begin{array}{l}\text { GEIRINHAS et } \\
\text { al., } 2019 \\
\text { INMET, } 2010 \\
\text { EPE, } 2010\end{array}$ \\
\hline 2014 & $\begin{array}{l}\text { South/ } \\
\text { Southeast }\end{array}$ & Heatwave & $\begin{array}{l}\text { In February, the South and Southeast regions } \\
\text { showed positive temperature deviations above } \\
5^{\circ} \mathrm{C} \text { compared to the historical average of } 1961 \\
-1990 \text { for the month. All states in the South and } \\
\text { Southeast regions experienced significant electricity } \\
\text { consumption, with a growth of } 12.2 \% \text { in the } \\
\text { Southeast and } 26.5 \% \text { in the South. }\end{array}$ & $\begin{array}{l}\text { CEInfo, } 2014 \\
\text { INMET, 2014a } \\
\text { EPE, } 2014\end{array}$ \\
\hline 2014 & $\begin{array}{l}\text { Mid-West } \\
\text {-South }\end{array}$ & Heatwave & $\begin{array}{l}\text { The Mid-West and South regions recorded } \\
\text { maximum temperatures between } 5 \text { ㅇ C to } 10 \text { ㅇ C } \\
\text { above the normal climatological maximum from } \\
1961 \text { to } 1990 \text {, characterizing the heatwave event } \\
\text { in the period from } 13 \text { to } 17 \text { October. That month, } \\
\text { household consumption was } 5.2 \% \text {, higher than the } \\
\text { same period in } 2013 \text {, showing the Mid-West region } \\
\text { with an increase of consumption of } 13.4 \% \text {. }\end{array}$ & $\begin{array}{l}\text { INMET,2014b } \\
\text { EPE, 2014b }\end{array}$ \\
\hline 2015 & $\begin{array}{l}\text { North/ } \\
\text { Southeast/ } \\
\text { Mid-West }\end{array}$ & Heatwave & $\begin{array}{l}\text { In the Mid-West region, the city of Cuiabá (MT) } \\
\text { recorded a period of } 8 \text { consecutive days with } \\
\text { temperatures } 6^{\circ} \mathrm{C} \text { above the historical average } \\
\text { of the month. Brasilia (DF) registered a heatwave } \\
\text { with temperatures up to } 9 \text { o } \mathrm{C} \text { above the average } \\
\text { maximum of the month ( } 1961 \text { to } 1990) \text {. In the } \\
\text { Southeast, high temperatures were observed, } \\
\text { especially in Minas Gerais, where the maximum } \\
\text { average temperature varied by up to } 6^{\circ} \mathrm{C} \\
\text { above the climatological average (1961-1990) } \\
\text { for approximately } 15 \text { days. In Rio de Janeiro, } \\
\text { temperatures were measured } 5 \text { oC above the } \\
\text { climatological average (1961-1990) for } 11 \text { days in } \\
\text { October. }\end{array}$ & $\begin{array}{l}\text { INMET, } 2015 \\
\text { EPE, 2015a } \\
\text { EPE, 2015b }\end{array}$ \\
\hline 2019 & Southeast & Heatwave & $\begin{array}{l}\text { In January, there were } 22 \text { days in Rio de Janeiro } \\
\text { with temperatures } 5^{\circ} \mathrm{C} \text { above the climatological } \\
\text { average from } 1961 \text { to } 1990 \text {. The city of São Paulo } \\
\text { recorded } 14 \text { days of maximum temperatures above } \\
\text { the historical average. Residential consumption } \\
\text { in the Southeast grew } 8.3 \% \text { compared to January } \\
2018 \text {. }\end{array}$ & $\begin{array}{l}\text { INMET, } 2019 \\
\text { EPE, 2019b }\end{array}$ \\
\hline 2019 & Mid-West & Heatwave & $\begin{array}{l}\text { In September, an extreme temperature event } \\
\text { reached the Mid-West region. According to } \\
\text { the heatwave alert issued by INPE/CPTEC, the } \\
\text { temperature remained 50C above the historical } \\
\text { average (1961 -1990) for the month, for a period } \\
\text { longer than five days. Electricity consumption in the } \\
\text { Mid-West region in that month had an increase of } \\
13.4 \% \text { compared to the previous year. }\end{array}$ & $\begin{array}{l}\text { INMET, 2019b } \\
\text { EPE, 2019c } \\
\text { INMET, 2019c }\end{array}$ \\
\hline
\end{tabular}

\subsection{IMPACTS OBSERVED IN BIOENERGETIC CROPS}

The drought that hit the Southeast of Brazil in 2014 resulted in a major impact on the productivity of sugarcane fields, especially in the state of São Paulo, the largest producer of sugarcane in Brazil (NOBRE et al., 2016). There was a 7.3\% drop in average productivity in the Midwest and Southeast Region in the 2014/2015 harvest compared to the previous season, reaching $11 \%$ in the state of São Paulo (CONAB, 
2017). Such drop in productivity in the main producing region of the country represented a lower production in the period for Brazil, which amounted to approximately 634 million tons of crushed sugarcane in the $2014 / 2015$ harvest, $2.7 \%$ less than in the previous harvest, despite the $12 \%$ increase in production in the North-Northeast producing region in the harvest, which reached about 61 million tons of sugarcane milled (UNICA, 2020).

The drought context in the Midwest and Southeast Regions in the 2014/2015 harvest, despite having a profound impact on the production of sugarcane fields, ended up favoring a higher concentration of total recoverable sugars (ATR - as in its Portuguese acronym from Açúcares Totais Recuperáveis) in the culms of the plants, due to the favorable conditions in the maturation phase. The average content recorded in the harvest for the Midwest and Southeast were $136.58 \mathrm{~kg}$ of ATR / ton of sugarcane, an increase of $2.45 \%$ in relation to the previous harvest (UNICA, 2015).

Regarding ethanol, despite the absolute drop in the production of total recoverable sugars recorded compared to the previous harvest of $1.97 \%$, the Midwest and Southeast Regions recorded a higher total fuel production, reaching $26,146 \mathrm{~m}^{3}$ in $2014 / 2015$ against $25,575 \mathrm{~m}^{3}$ in the previous harvest. Therefore, sugar production was reduced by $6.73 \%$ compared to the previous season, reaching a total of 31,987 thousand tons (UNICA, 2015).

The 2015/2016 soybean harvest was affected by drought in areas in the North and Northeast regions of the country, especially in Matopiba, an acronym for the agricultural production region comprised by the Northeast and North states of Maranhão, Tocantins, Piauí, and Bahia. The lack of rain in November, the most suitable period for planting in the region, forced producers to postpone sowing. In addition, the high temperatures and periods of drought observed during the development of the crop strongly impacted its productivity. The averages obtained in the harvest ranged from $2.1 \mathrm{t} / \mathrm{ha}$ to $1.1 \mathrm{t} / \mathrm{ha}$ in the states of the region, representing decreases of $37 \%$ to $62 \%$ in relation to the maximum average productivity already observed until then in the respective states, close to $3.2 \mathrm{t} / \mathrm{ha}$ (HIRAKURI, 2016).

The productivity drop observed in the Matopiba region led to a reduction in total soybean production in Brazil in the 2015/2016 harvest, despite the increase observed in production in the South and Southeast regions. Production in Brazil in the 2015/2016 harvest was 95.4 million tons of soybeans against 96.2 million tons in the previous year (CONAB, 2020).

Regarding the production of biodiesel, there was a 3.5\% decrease in 2016 compared to 2015, with production being reduced in all geographic regions, except the South. Soy oil remained the main raw material for fuel production, representing $79.1 \%$ of the total (ANP, 2017). It should be noted, however, that it is difficult to affirm that there is a direct correlation between climatic stress for soybean production in the Matopiba region and the supply of biodiesel in Brazil given some circumstances. Firstly, most of the soybean production is destined for export in the form of grains, with a considerably lower portion led to crushing in the country for the production of oil and bran (CONAB, 2020). Also, the biodiesel production capacity is concentrated in the South and Mid-West regions, while the combined production capacity of the North and Northeast regions accounts for less than $10 \%$ of the country's total in 2016 (ANP, 2017).

A relevant factor to be considered is that the demand for biodiesel depends essentially on the demand for diesel by the transport sector and the minimum mandatory percentage of biodiesel in diesel, which is currently $12 \%$, with the forecast of reaching $15 \%$ in 2023 with increases of $1 \%$ per year (BRASIL, 2018). Thus, the expected increase in the mandatory minimum content, followed by an increase on diesel demand may intensify the impacts of soybean crop losses in the biodiesel chain. Table 4 presents the impacts of climatic events in Brazilian bioenergetic crops between 2011 and 2020. 
Table 4 | Impacts of extreme events in the cultivation of soy and sugarcane between 2011 and 2020

\begin{tabular}{|c|c|c|c|c|c|}
\hline Crop & Harvest & Region & $\begin{array}{c}\text { Type of climate } \\
\text { impact }\end{array}$ & Description & Reference \\
\hline Soy & $2011 / 2012$ & South (RS) & Drought & $\begin{array}{l}\text { The prolonged drought in the southern } \\
\text { part of South America hampered the } \\
\text { development of soybean plantations } \\
\text { in the state of Rio Grande do Sul } \\
\text { that year. The average value of } \\
\text { crop productivity was } 1.55 \mathrm{t} / \mathrm{ha} \text {, } \\
\text { representing a drop of } 45 \% \text { compared } \\
\text { to the previous harvest. }\end{array}$ & $\begin{array}{l}\text { EMATER/RS- } \\
\text { Ascar, 2012; } \\
\text { HIRAKURI, } \\
2016 \\
\text { Portal } \\
\text { Agronotícias, } \\
2020\end{array}$ \\
\hline Soy & $2015 / 2016$ & MATOPIBA* & $\begin{array}{l}\text { Drought, } \\
\text { High mean } \\
\text { termperatures }\end{array}$ & $\begin{array}{l}\text { The weather conditions for the } \\
\text { cultivation of soybeans in the } \\
2015 / 2016 \text { harvest were adverse for } \\
\text { Brazil, in general, resulting in a } 4.3 \% \\
\text { reduction of the average productivity } \\
\text { of the crop in the country in relation to } \\
\text { the previous year, breaking a historical } \\
\text { increase trend. The MATOPIBA } \\
\text { producing region suffered the greatest } \\
\text { impacts, due to drought at the time } \\
\text { of planting, which delayed sowing, } \\
\text { followed by a period of drought and } \\
\text { high temperatures. The states of } \\
\text { Mato Grosso, Mato Grosso do Sul, } \\
\text { and Paraná also showed declines in } \\
\text { productivity in this harvest compared } \\
\text { to the previous year. }\end{array}$ & $\begin{array}{l}\text { HIRAKURI, } \\
2016 \\
\text { CONAB, } \\
2020\end{array}$ \\
\hline Soy & $2019 / 2020$ & South (RS) & Drought & $\begin{array}{l}\text { The drought that occurred during } \\
\text { the soybean cultivation cycle in Rio } \\
\text { Grande do Sul resulted in a historic } \\
\text { crop failure for the state's crop. The } \\
\text { average soybean yield in the state was } \\
1.79 \text { t/ha, representing a decrease of } \\
\text { approximately } 46 \% \text { in the estimated } \\
\text { value at the beginning of cultivation. } \\
\text { In the six previous harvests, } \\
\text { productivity had varied between } 2.60 \\
\text { and } 3.36 \text { t/ha. }\end{array}$ & $\begin{array}{c}\text { EMATER/RS- } \\
\text { Ascar, } 2020 \\
\text { CONAB, } \\
2020\end{array}$ \\
\hline Sugarcane & $2014 / 2015$ & $\begin{array}{l}\text { Mid- } \\
\text { west and } \\
\text { Southeast }\end{array}$ & Drought & $\begin{array}{l}\text { The severe drought that caused a } \\
\text { period of intense water restriction } \\
\text { in the Southeast of Brazil, especially } \\
\text { in the State of São Paulo, severely } \\
\text { impacted the } 2014 / 2015 \text { crop in the } \\
\text { Mid-west and Southeast producing } \\
\text { regions, which had its agricultural } \\
\text { productivity reduced by } 7.3 \% \text { in } \\
\text { comparison to the previous harvest. } \\
\text { This reduction reached } 11 \% \text { on average } \\
\text { in the state of São Paulo, the largest } \\
\text { producer of sugarcane in the country. }\end{array}$ & $\begin{array}{c}\text { CONAB, } \\
2017\end{array}$ \\
\hline Sugarcane & $2018 / 2019$ & $\begin{array}{l}\text { Mid-west, } \\
\text { Southeast } \\
\text { and South } \\
\text { (São Paulo, } \\
\text { Mato Grosso } \\
\text { do Sul and } \\
\text { Paraná) }\end{array}$ & Drought & $\begin{array}{l}\text { The drought that occurred between } \\
\text { February and July } 2018 \text { in some } \\
\text { productivity areas of those states, } \\
\text { which had a rainfall rate } 34 \% \text { below } \\
\text { the historical average, impacted } \\
\text { the production of sugar cane in the } \\
2018 / 2019 \text { harvest. The harvest } \\
\text { recorded a crushing rate } 4 \% \text { lower than } \\
\text { the previous harvest in the region. }\end{array}$ & $\begin{array}{c}\text { GOMES, } \\
2018 \\
\text { UNICA, } 2020\end{array}$ \\
\hline
\end{tabular}




\begin{tabular}{|c|c|c|c|l|c|}
\hline Crop & Harvest & Region & $\begin{array}{c}\text { Type of climate } \\
\text { impact }\end{array}$ & Description & Reference \\
\hline Sugarcane & $2019 / 2020$ & $\begin{array}{l}\text { Mid-west, } \\
\text { Southeast } \\
\text { and South } \\
\text { São Paulo, } \\
\text { Mato Grosso } \\
\text { do Sul and } \\
\text { Paraná) }\end{array}$ & Frost & $\begin{array}{l}\text { A frost that occurred in early July } \\
2019 \text { in those productivity zones } \\
\text { impacted an area equivalent to 400 } \\
\text { thousand hectares of sugarcane fields, } \\
\text { of which about } 65 \% \text { had not yet been } \\
\text { harvested. It is estimated that the } \\
\text { impact of this climatic event reduced } \\
\text { crop productivity by up to 5 t/ha. }\end{array}$ & $\begin{array}{c}\text { SAMORA, } \\
2019\end{array}$ \\
\hline
\end{tabular}

Source: The authors of this study

\section{DISCUSSION}

The impacts observed on the energy system due to climatological factors attest to the importance of adaptation measures to guarantee greater energy security in Brazil. Energy planning is carried out to identify future energy needs, in order to meet the projected demand. Considering climate-related impacts and vulnerabilities in the energy planning process strengthens the resilience and adaptability of the energy system. Also, it is necessary that future energy planning consider mitigation measures for GHGs to define adaptation strategies that are sustainable over time.

The first Nationally Determined Contribution - NDC, commitment assumed by the Country for 2030 within the scope of the Paris Agreement of 2015 (MCTIC, 2019), seeks to ensure 45\% of renewable sources in the primary energy matrix, expand participation of non-hydraulic renewable sources to a level between $28 \%$ and $33 \%$ and an increase the share of biofuels to $18 \%$. Additionally, EPE (2018) indicates the possibility of achieving $10 \%$ efficiency gains in the electricity sector. Thus, the great challenge for the energy sector is to comply with the Brazilian NDC considering climate change and its impact on renewable energies. Also, the expected increase in electricity demand in the residential sector, given the need for cooling for thermal comfort, makes increasing energy efficiency more challenging.

The Plans support decision-making in energy expansion projections. They provide plenty of information on market studies, sectors of the energy chain, system performance indicators, and investment requirements, among others (EPE, 2017a). In addition, they also serve as a basis for bidding for the contracting of new energy, which takes place through auctions.

To this end, it is necessary to carry out studies with future climate change scenarios. The results could be considered in the planning instruments for the energy sector, Ten-Year Energy Expansion Plan (PDE as in its Portuguese acronym) and National Energy Expansion Plan (PNE as in its Portuguese acronym), with regard to the expansion of energy supply, demand and transport and other aspects. Conducting these studies and incorporating them into energy auctions can be considered low-cost when compared to the impacts of climate change on energy production and the energy infrastructure. The study of future climate change scenarios in the energy system can be carried out in the medium term.

Thus, an analysis of options for adapting the energy sector is very relevant. These options, however, must also consider the impact on water, food, socio-environmental, and climate security.

The Brazilian interconnected system has a good diversity of the electricity matrix, which makes it possible to compensate for climate change impacts on power generation. This compensation provides the power system with an intrinsic adaptation capacity (BRASIL, 2016b). However, it is necessary to consider the possible variation in generation costs, GHG emissions, as well as in electricity demand, variables that are related to energy security. The analysis carried out in the previous sections shows the vulnerability of water resources for hydropower, especially in the Northeast Region. Also, other studies show the possibility of increasing wind and solar potential in Brazil. However, the high participation of hydroelectric generation makes an impact on the SIN more significant. In response, the adaptive 
capacity of the SIN can increase the participation of thermoelectric plants in fossil fuels or biomass to meet the demand for electricity (LUCENA et al., 2018).

Thermoelectric generation can lead to an increase in emissions of local air pollutants, with consequences for people's health (PORTUGAL-PEREIRA et al., 2018). Furthermore, the final price of electricity may increase due to the fuel consumption and the investments in the installation, operation, and maintenance of new thermoelectric plants (EPE, 2017). This affects the population and all economic sectors. Moreover, the demand and consumption of water resources will depend on the cooling technology that the thermoelectric plants use (ARROYO, 2018). The effluents generated could also impact the quality of water resources and aquatic ecosystems (ARROYO, 2018).

Furthermore, there is the possibility of creating hybrid plants, so that photovoltaic and wind systems can be installed close to the reservoirs and produce electricity to compensate for the losses of hydroelectric generation due to droughts. The integration of photovoltaic systems to the Três Marias plant, for instance, could make it a hybrid solar-hydro plant with a higher generation capacity factor.

The abundance of solar resources in periods of scarcity in the São Francisco River basin would result in a high photovoltaic generation, offsetting the losses from hydroelectric generation in the same period (VELLOSO, 2017). The implementation of floating photovoltaic systems in hydroelectric reservoirs would be another important adaptation measure, as it contributes to a greater generation of electric energy and a reduction in the evaporation of the reservoirs, thus slowing down the drop in the level of the reservoirs during the dry period (FARFAN; BREYER, 2018).

The impact of extreme events, such as cyclones and heavy rainfalls, on transmission and distribution systems can be mitigated by encouraging off-grid distributed generation systems, based on biomass and solar energy, in consumer units connected to the grid. If the supply of electricity is interrupted during these events, a residential photovoltaic system with energy storage in batteries, for example, can be activated and maintain the electricity supply of the residence in which it is located (IRENA, 2019). Finally, studies to identify and analyze the greatest number of interruptions in energy transport systems due to the extreme events would support the strengthening of actions for resilience to the future impacts. Both options strengthen the energy security of the electricity supply and, consequently, the socioeconomic security.

Figure 5 shows adaptation options proposed for the power system and their relationship with other security measures. 


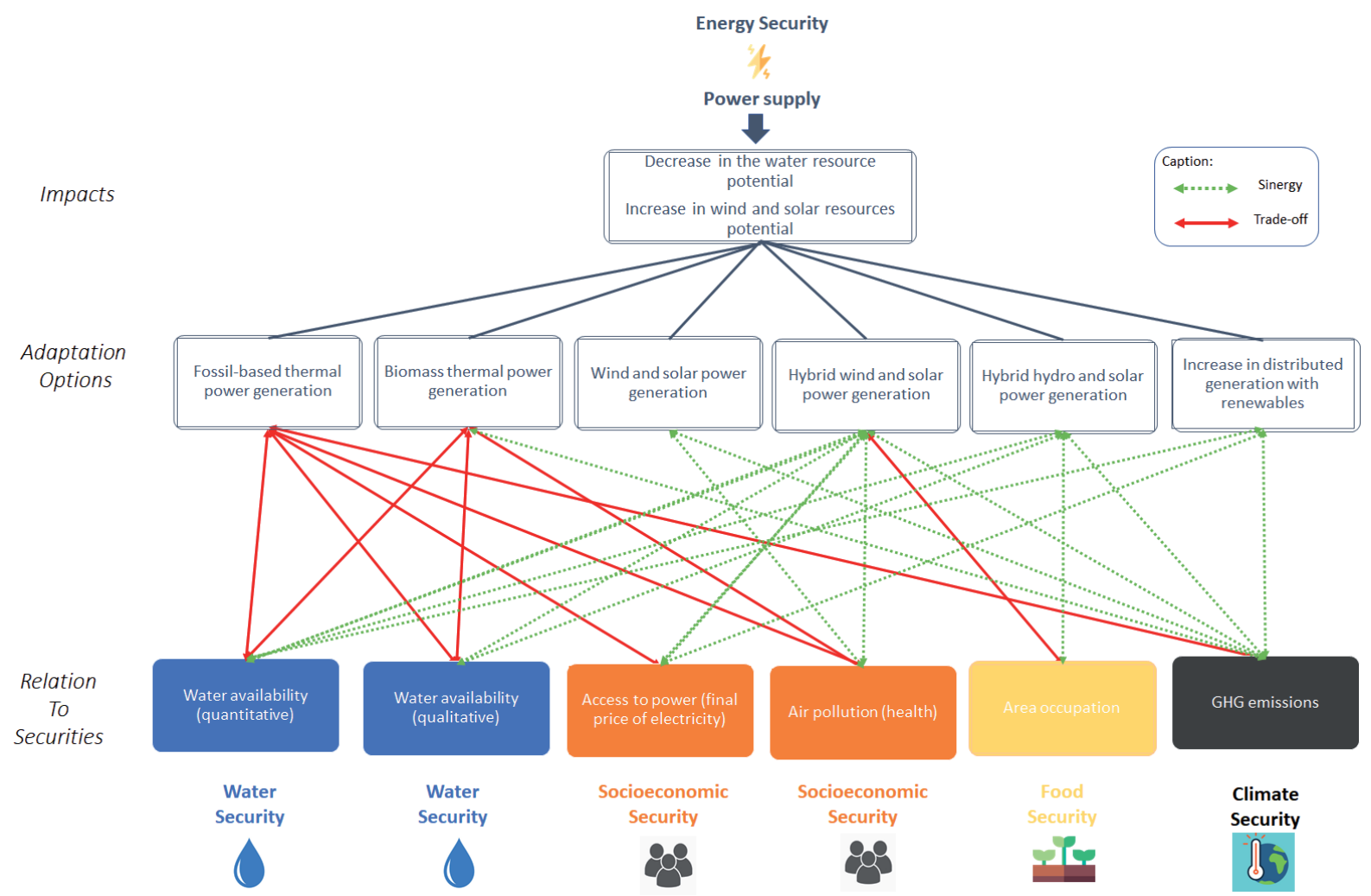

Figure 5 | Adaptation options for the supply of the electricity sector and its interaction with water, food, socioeconomic, and climate security

Source: The authors of this study. This figure was drawn using Flaticon.com resources.

The negative impact related to electricity consumption during heatwaves events, the strengthening of government energy management, guided by energy conservation policies, can reduce energy demand. Management must be directed towards the efficiency of all energy consumption sectors, such as buildings, industry, and transport.

The strengthening should be directed to aspects of management instruments by the public sector, technological aspects in the search for more efficient equipment, and to promoting behavioral change in the population and other energy users. As an aggravating factor in this context, the rise in air temperature may influence the increase in electricity demand for cooling in different sectors. In the building sector, the greater use of cooling devices maintains the thermal comfort (health) of people. The adaptive measure creates feedback, since the increase in energy consumption, especially during peak hours, can lead to an increase in GHG emissions (DEPAULA and MENDELSOHN, 2010).

In addition, it is important to strengthen technical construction standards with sustainable energy conservation measures for all sectors: residential, commercial, services and public buildings, and industrial enterprises. Energy efficiency standards should be considered to all sectors, such as those indicated by Procel Buildings, which evaluate the enveloping, lighting, and air conditioning systems. Also, management must be integrated with the urban planning of natural cooling systems (passive cooling) such as green spaces on roofs, for example.

Finally, the increase in climatic risk for sugarcane and soybeans due to droughts, evidenced by Costa (2019), Pires et al. (2016), and Zullo et al. (2018), can be mitigated by more efficient irrigation methods and by the genetic improvement of crops to allow their adaptation in regions with different climates (ZULLO et al., 2018). This achievement proves the technical capacity of Brazilian agriculture to adapt important crops to new edaphoclimatic conditions (FREITAS, 2011). Carvalho and Furtado (2013) point out that there are important technological centers for the research of sugarcane in Brazil, which are 
capable of providing the necessary answers to the expected climate adversities. However, it is observed that research in the country currently focuses on short-term issues, such as increased productivity and effective pest control.

\section{FINAL CONSIDERATIONS}

The present study is aimed to analyze the impacts of extreme events in the Brazilian energy system, analyzing them qualitatively. In this way, evident occurrences of the vulnerability of the energy sector show that planning considering climate change should not only take into account the long term but also the short and medium-term scenarios. Thus, this approach can provide valuable information for decision-makers. The discussion of adaptation options and their interaction with other security measures also highlights the need for integrated management so that it is sustainable over time. Finally, climate change must not be understood as a distant problem, and there must be a current commitment of financial and human resources for both mitigation and adaptation.

\section{ACKNOWLEDGMENTS}

The present study was carried out with the support of the Coordination for the Improvement of Higher Education Personnel (CAPES) - Financing Code 001, the National Council for Scientific and Technological Development (CNPq) and the National Institute of Science and Technology for Climate Change (INCT-MC).

\section{REFERENCES}

ANA. Sistema de Acompanhamento de Reservatórios - SAR. 2019. Disponível em: <http://sar.ana.gov.br/ MedicaoSin>. Acesso em: 19 ago. 2020.

ANEEL. Aneel conclui revisão tarifária da Escelsa (ES), Iguaçu (SC) e Celesc (SC). 2004. Disponível em: <http:// www.aneel.gov.br>. Acesso em: 20 jul. 2020.

ANEEL. Atlas de Energia Elétrica do Brasil. Parte I: Energia no Brasil e no mundo. 2005. Disponível em: <http:// www2.aneel.gov.br/arquivos/pdf/atlas_par1_cap1.pdf.> Acesso em: 20 jul. 2020.

ANEEL. Relatório de Análise: desligamentos forçados do sistema de transmissão. 2016.

ANEEL. Desligamentos Forçados do Sistema de Transmissão. 2018.

ANEEL. Capacidade de Geração do Brasil. 2018. Disponível em: <http://www2.aneel.gov.br>. Acesso em: 15 ago. 2020.

ANP. Anuário Estatístico Brasileiro do Petróleo, Gás Natural e Biocombustíveis 2020. Brasília, 2020.

ARIAS, M. et al. Impacts of climate change and deforestation on hydropower planning in the Brazilian Amazon. Nature Sustainability, v. 3, n. 6, p. 430-436, 2020.

ARROYO, E. Incorporação do nexo energia-água em um modelo de otimização da expansão do sistema energético brasileiro. Tese (Doutorado). Programa de Pós-Graduação em Planejamento Energético. Coppe - Universidade Federal do Rio de Janeiro, Rio de Janeiro, 2018.

BRASIL. Ministério do Meio Ambiente. Plano Nacional de Adaptação à Mudança do Clima. Estratégia Geral. Ministério do Meio Ambiente. Secretaria de Mudança do Clima e Florestas. Brasília, DF: MMA, 2016a. Disponível em: <https://www.mma.gov.br>. Acesso em: 19 ago. 2020.

BRASIL. Conselho Nacional de Política Energética. Resolução $\mathbf{N}^{\circ}$ 16, de 29 de outubro de 2018. Dispõe sobre a evolução da adição obrigatória de biodiesel ao óleo diesel vendido ao consumidor final, em qualquer parte do território nacional. Brasília, DF: CNPE, 2018. Disponível em: <http://www.mme.gov.br>. Acesso em: 20 ago. 2020. 
BRASIL. Ministério da Ciência, Tecnologia, Inovações e Comunicações. Acordo de Paris. Publicação Bilíngue do Acordo de Paris - Inglês e Português, Brasília, 2018.

BRASIL. Ministério do Meio Ambiente. Pretendida Contribuição Nacionalmente Determinada. Brasília, DF, 2015. Disponível em: <https://www.mma.gov.br.> Acesso em: 20 ago. 2020.

BRASIL. Lei no 9.433, de 8 de janeiro de 1997. Institui a Política Nacional de Recursos Hídricos, cria o Sistema Nacional de Gerenciamento de Recursos Hídricos, regulamenta o inciso XIX do art. 21 da Constituição Federal, e altera o art. 1ㅇ da Lei no 8.001, de 13 de março de 1990, que modificou a Lei no 7.990, de 28 de dezembro de 1989. Diário Oficial da União, Brasília, DF, 9 jan. 1997. Disponível em: <http://bit.ly/1iC6rDg>. Acesso em: 22 ago. 2020.

CEEE. Câmara dos Deputados do Brasil. Comissão Externa Destinada a Acompanhar a Situação de Emergência no Estado de Santa Catarina. 2012. Relatório de Atividades. Março de 2017. 2017.

CEEE. Comunicado aos Clientes da CEEE Distribuição. [on-line] Portal CEEE, 2020. Disponível em: <https://www. ceee.com.br/noticias/comunicado-aos-clientes-da-ceee-distribuiaao>.

CEINFO. Boletim CEInfo Análise. A onda de calor de fevereiro de 2014 e o excesso de mortes no município de São Paulo, Ano IX, no 9, Rio de Janeiro, 2014. Disponível em: <https://www.prefeitura.sp.gov.br/cidade/secretarias/ upload/saude/arquivos/publicacoes/Boletim_Analise_09.pdf>. Acesso em: 20 de jul. 2020.

CEMADEN. Relatório da Situação Atual da Seca no Semiárido Brasileiro e Impactos, 2016.

CEMADEN. Boletim Monitoramento de Secas e Impactos no Brasil. p. 0-13. Abril, 2020.

CEMIG. Usina Hidrelétrica de Três Marias. 2019. Disponível em: <http://www.cemig.com.br/pt-br/a_cemig/ Nossa_Historia/Paginas/Usinas_Hidreletricas.aspx.> Acesso em: 19 ago. 2020.

CLARKE, L. et al. Effects of long-term climate change on global building energy expenditures. Energy Economics, v. 72, p. 667-677, 2018

CONAB. Perfil do Setor do Açúcar e do Etanol no Brasil: edição para a safra 2014/15. Companhia Nacional de Abastecimento. Brasília, 2017.

CONAB. Boletim de Safra de grãos, $11^{\circ}$ levantamento: safra 2019/2020. 2020. Disponível em: <https://www. conab.gov.br/info-agro/safras/graos/boletim-da-safra-de-graos?limitstart=0>. Acesso em: 20 ago. 2020.

COSTA, M. H. et al. Climate risks to Amazon agriculture suggest a rationale to conserve local ecosystems. Frontiers in Ecology and the Environment, v. 17, n. 10, p. 584-590. 2019.

CUNHA, A. et al. Secas e seus Impactos no Brasil em 2018, v. 1, p. 1-19. 2019a. Disponível em: <http://www. cemaden.gov.br/categoria/monitoramento/boletim-de-impactos>. Acesso em: 10 ago. 2020.

CUNHA, A. et al. Extreme drought events over Brazil from 2011 to 2019. Atmosphere, v. 10, n. 11, 2019b.

DEPAULA, G.; MENDELSOHN, R. Development and the impact of climate change on energy demand: evidence from Brazil. Climate Change Economics, v. 1, n. 03, p. 187-208, 2010.

ELETROSUL. Relatório anual e de sustentabilidade Eletrosul. Florianópolis: [s.n.], 2014. Disponível em: <http:// www-en.eletrosul.gov.br/files/files/sustentabilidade/relatorios-de-sustentabilidade/RELATÓRIO ANUAL E DE SUSTENTABILIDADE ELETROSUL 2014(1).pdf>. Acesso em: 15 ago. 2020.

EMATER/RS-Ascar. Informativo Conjuntural. Emater/RS-Ascar. Gerência de Planejamento. Núcleo de Informações e Análises. Jun. 1989. Porto Alegre, 2020.

EPE. Resenha Mensal do Mercado de Energia Elétrica. Ano III. n. 30, Rio de Janeiro, 2010.

EPE. Resenha mensal do mercado de energia elétrica. Ano VII, n. 78, Rio de Janeiro, 2014a.

EPE. Resenha mensal do mercado de energia elétrica. Ano VII, n. 86. Rio de Janeiro, 2014b. 
EPE. Resenha mensal do mercado de energia elétrica. Ano IX, n. 97. Rio de Janeiro, 2015a.

EPE. Resenha mensal do mercado de energia elétrica. Ano IX, n. 98. Rio de Janeiro, 2015b.

EPE. Plano Decenal de Expansão de Energia 2026. Ministério de Minas e Energia. MME/EPE. Brasília. 2017.

EPE. Mudanças Climáticas e Desdobramentos sobre os Estudos de Planejamento Energético: considerações iniciais. 2018.

EPE. Brazilian Energy Balance. 2019. Year, 2018 p. 303, 2019.

EPE. Resenha mensal do mercado de energia elétrica. Ano XII, n. 137. Rio de Janeiro, 2019b.

EPE. Resenha mensal do mercado de energia elétrica. Ano XII, n. 145. Rio de Janeiro, 2019c.

EPE. Solar Fotovoltaica Flutuante. 2020.

FARFAN, J.; BREYER, C. Combining floating solar photovoltaic power plants and hydropower reservoirs: a virtual battery of great global potential. Energy Procedia, v. 155, p. 403-411, 2018. Disponível em: <https://doi. org/10.1016/j.egypro.2018.11.038>. Acesso em: 15 dez. 2020.

FORRESTER, S. Residential Cooling Load Impacts on Brazil's Electricity Demand. 2019. Tese (Doutorado), p. $33,2019$.

GEIRINHAS, J. L. et al. Characterizing the atmospheric conditions during the 2010 heatwave in Rio de Janeiro marked by excessive mortality rates. Science of the Total Environment, v. 650, p. 796-808, Rio de Janeiro, 2019.

GLEICK, P. H. Impacts of California's Ongoing Drought: hydroelectricity generation. Pacific Institute, n. February, p. 1-14, 2016.

GOMES, J. Tempo seco e lavoura envelhecida reduzem safra de cana 18/19 no centro-sul, diz FCStone. Reuters/ Portal Terra. 2018. Disponível em: <https://www.terra.com.br/economia/tempo-seco-e-lavoura-envelhecidareduzem-safra-de-cana-1819-no-centro-sul-diz-fcstone,daaddbe27b3601e3c21dcb1ebc6e94dap09xce9y.html>. Acesso em: 20 ago. 2020.

HIRAKURI, M. Impactos econômicos de estresses na produção de soja da safra 2015/16. Circular Técnica, 125. Londrina, PR: Empresa Brasileira de Pesquisa Agropecuária, p. 8. 2016.

INMET. Boletim Agroclimatológico mensal, v. 44, n. 01, 2010. Disponível em: <http://www.inmet.gov.br/portal/ arq/upload/BOLETIM-AGRO_MENSAL_201002.pdf .EPE>. Acesso em: 20 jul. 2020.

INMET. Boletim Agroclimatológico Mensal, v. 48, n. 02, 2014a. Disponível em: <http://www.inmet.gov.br/portal/ arq/upload/BOLETIM-AGRO_MENSAL_201402.pdf> Acesso em: 20 jul. 2020.

INMET. Boletim Agroclimatológico Mensal, v. 48, n. 10, 2014b. Disponível em: <http://www.inmet.gov.br/portal/ arq/upload/BOLETIM-AGRO_MENSAL_201410.pdf> Acesso em: 20 jul. 2020.

INMET. Boletim agroclimatológico mensal, v. 49, n.09, 2015. Disponível em: <http://www.inmet.gov.br/portal/ arq/upload/BOLETIM-AGRO_MENSAL 201509.pdf> Acesso em: 20 jul. 2020.

INMET. Boletim Agroclimatológico Decendial. 2019a. Disponível em: <http://www.inmet.gov.br/portal/arq/ upload/BOLETIM-AGRO_DECENDIAL_201901.pdf>. Acesso em: 23 jul. 2020.

INMET. Boletim Agroclimatológico Mensal, v. 54, n. 03, 2019b. Disponível em: <http://www.inmet.gov.br/portal/ arq/upload/BOLETIM-AGRO_MENSAL_201910.pdf>. Acesso em: 23 jul. 2020.

INMET. Alert-AS - Centro Virtual para Avisos de Eventos Meteorológicos Severos. 2019c. Disponível em: <http://alert-as.inmet.gov.br/cv/emergencia/cap/10598?fbclid=IwAROMsQMIBb-8 it670SwhkEZMd5hFzJyVUv5NBOeVEbImvkJI4nU_q4wikl> Acesso em: 23 jul. 2020.

INVIDIATA, A.; GHISI, E. Impact of climate change on heating and cooling energy demand in houses in Brazil. Energy and Buildings, v. 130, p. 20-32, 2016. 
IPCC. Wind Energy. In: IPCC Special Report on Renewable Energy Sources and Climate Change. IPCC Special Report on Renewable Energy Sources and Climate Change Mitigation, 2011.

IPCC. Climate Change 2014: synthesis report, contribution of working groups I, II and III to the fifth assessment report of the Intergovernmental Panel on Climate Change. v. 1, n. October, p. 1-169, 2014b. 2014.

IRENA. Off-grid renewable energy solutions to expand electricity access: an opportunity not to be missed. International Renewable Energy Agency, Abu Dhabi, p. 144, 2019.

JEREZ, S. The impact of climate change on photovoltaic power generation in Europe. Nature Communications, $\mathrm{v}$. 6, 2015.

JONG, P. et al. Estimating the impact of climate change on wind and solar energy in Brazil using a South American regional climate model. Renewable Energy, v. 141, p. 390-401, 2019.

LELIS, T. A. et al. Impactos causados pelas mudanças climáticas nos processos erosivos de uma bacia hidrográfica: simulação de cenários. Impacts of climate change on erosion of a watershed: simulation of scenarios. Revista Ambiente \& Água, v. 6, n. 2, p. 282, 2011.

LUCENA, A. et al. Interactions between climate change mitigation and adaptation: the case of hydropower in Brazil. Energy, 164, p.1161-1177, 2018.

LUCENA, A. et al. The vulnerability of renewable energy to climate change in Brazil, Energy Policy, v. 37, n. 3, p. 879-889, 2009.

MARENGO, J. Vulnerabilidade, impactos e adaptação à mudança do clima no semiárido do Brasil. Cachoeira Paulista v. CPTEC/Inpe, p. 16. 2004.

MARENGO, J. et al. A seca e a crise hídrica de 2014-2015 em São Paulo. Revista USP, v. 106, n. 31, 2015.

MARENGO, J. et al. Climatic characteristics of the 2010-2016 drought in the semiarid northeast Brazil region. Anais da Academia Brasileira de Ciências, v. 90, n. 2, p. 1973-1985, 2018.

MARTINS, E.; FRANCISCO JÚNIOR. O clima da Região Nordeste entre 2009 e 2017: monitoramento e previsão. Parc. Estrat., v. 22, n. 44, p. 63-80, 2017.

A seca de 2012-2015 no Nordeste e seus impactos. Parcerias Estratégicas, 107-128, 2015.

NOBRE, C. et al. Some Characteristics and Impacts of the Drought and Water Crisis in Southeastern Brazil during 2014 and 2015. Journal of Water Resource and Protection, v. 08, n. 02, p. 252-262, 2016.

ONG, P. et al. Hydroelectric production from Brazil's São Francisco River could cease due to climate change and inter-annual variability. Science of the Total Environment, v. 634, p. 1540-1553, 2018.

ONS. Disponível em: <http://www.ons.org.br>. Acesso em: 22 ago. 2020.

PEREIRA, E. B. et al. The impacts of global climate changes on the wind power density in Brazil. Renewable energy, v. 49, p. 107-110, 2013.

PEZZA, A. B.; SIMMONDS, I.; FILHO, A. J. P. Climate perspective on the large-scale circulation associated with the transition of the first South Atlantic hurricane. 2008. International Journal of Climatology, v. 29, n. 8, mar. 2018. p. 2011-2029.

PIRES, G. et al. Increased climate risk in Brazilian double cropping agriculture systems: implications for land use in Northern Brazil. Agricultural and forest meteorology, v. 228, p. 286-298, 2016.

PORTAL AGRONOTÍCIAS. Seca atual é comparada com a que provocou quebra na safra de 2012. Notícias/Clima e Temperatura. 2020. Disponível em: <http://www.portalagronoticias.com.br/noticia/7836/rs-seca-atual-ecomparada-com-a-que-provocou-quebra-na-safra-de-2012>. Acesso em: 20 ago. 2020.

PORTUGAL-PEREIRA et al. Interactions between global climate change strategies and local air pollution: lessons 
learnt from the expansion of the power sector in Brazil. 2018. Climatic Change. https://doi.org/10.1007/s10584018-2193-3.

SAILOR, D. J.; SMITH, M.; HART, M. Climate change implications for wind power resources in the Northwest United States. Renewable Energy, v. 33, n. 11, p. 2393-2406, 2008.

SAMORA, R. Moagem de cana do centro-sul cai abaixo de previsão: Unica cita perdas por geadas. Economia/ Notícias/Reuters/UOL. 2019. Disponível em: <https://economia.uol.com.br/noticias/reuters/2019/07/24/moagemde-cana-do-centro-sul-recua-95-na-1-quinzena-unica-cita-perdas-por-geadas.htm>. Acesso em: 20 ago. 2020.

SANTOS, A. Impacto de Mudanças Climáticas no Potencial de Energia Solar Fotovoltaica no Setor Residencial Brasileiro. 426f. Dissertação (Mestrado em Planejamento Energético) - Universidade Federal do Rio de Janeiro. Rio de Janeiro, 2020.

SCHAEFFER, R. et al. Adaptação às mudanças climáticas no Brasil: cenários e alternativas, p. 1-56, 2015.

SCHAEFFER, R. et al. Energy sector vulnerability to climate change: a review, energy, v. 38, n. 1, p. 1-12, 2012.

SIMIONI, T.; SCHAEFFER, R. Georeferenced operating-efficiency solar potential maps with local weather conditions - An application to Brazil. Solar Energy, v. 184, n. October 2018, p. 345-355, 2019.

SINGH, P.; RAVINDRA, N. M. Temperature dependence of solar cell performance: an analysis, solar energy materials and solar cells, v. 101, p. 36-45, 2012.

SIVAK, M. Potential energy demand for cooling in the 50 largest metropolitan areas of the world: implications for developing countries. Energy Policy, v. 37, n. 4, p. 1382-1384, 2009.

SKOPLAKI, E.; BOUDOUVIS, A. G.; PALYVOS, J. A. A simple correlation for the operating temperature of photovoltaic modules of arbitrary mounting. Solar Energy Materials and Solar Cells, v. 92, n. 11, p. 1393-1402, 2008.

TEIXEIRA, M. et al. Assaí: an energy view on an Amazon residue. Biomass and Bioenergy, 58, p. 76-86, 2013.

TOBIN, I. et al. Assessing climate change impacts on European wind energy from Ensembles high-resolution climate projections. Climatic Change, v. 128, n. 1-2, p. 99-112, 2015.

ÚNICA. Relatório final da safra 2014/2015: região centro-sul. São Paulo: União da Indústria de Cana-de-Açúcar, 2015.

ÚNICA. Relatório final da safra 2019/2020. 2020. Disponível em: <http://unicadata.com.br/listagem. php?idMn=118>. Acesso em: 22 ago. 2020.

VELLOSO, M. F. Possibilidade de geração híbrida hidrossolar na bacia do São Francisco, 145f. Tese (Doutorado em Ciência do Sistema Terrestre) - Instituto Nacional de Pesquisas Espaciais, São José dos Campos, 2017.

WANDERLEY, L. DE A. et al. As chuvas na cidade do Recife: uma climatologia de extremos. Revista Brasileira de Climatologia, v. 22, p. 149-164, 2018.

WORLD BANK. Avaliação de Perdas e Danos: inundações bruscas em Santa Catarina em novembro de 2008. 2012a. Disponível em: <http://documents1.worldbank.org/curated/en/250881468232500513/pdf/NonAsciiFileName0. pdf>. Acesso em: 20 ago. 2020.

WORLD BANK. Avaliação de Perdas e Danos: inundações bruscas em Pernambuco em junho de 2010. 2012 b. Disponível em: <http://documents1.worldbank.org/curated/pt/495391468013874079/pdf/NonAsciiFileName0. pdf $>$. Acesso em: 20 ago. 2020.

WORLD BANK. Avaliação de Perdas e Danos: inundações e deslizamentos na Região Serrana do Rio de Janeiro em janeiro de 2011. 2012c. Disponível em: <http://documents1.worldbank.org/curated/en/260891468222895493/ pdf/NonAsciiFileName0.pdf>. Acesso em: 20 ago. 2020.

ZULLO; J.; PEREIRA; V.; KOGA-VICENTE, A. Sugar-energy sector vulnerability under CMIP5 projections in the Brazilian central-southern macro-region. Climatic Change, v. 149, n. 3-4, p. 489-502, 2018. 